\title{
Board Characteristics and Bank Performance: Evidence from Iraq
}

\author{
Hamid Mohsin Jadah ${ }^{1}$ \\ Logasvathi A/P Murugiah ${ }^{2}$ \\ Azira Binti Abdul Adzis ${ }^{3}$
}

\begin{abstract}
This paper presents the key role of corporate governance on the performance of banks in Iraq. This study aims to examine the relationship between board characteristics and bank performance by considering panel data of 24 banks for period 2005-2014 in Iraq. This relationship is estimated by using the panel OLS and regression technique. The findings reveal there is a significant positive relationship between board composition, board size and bank performance. Additionally, findings show that female board of directors is one of the reasons to make down the bank performance in Iraq. Taken together, this study finding recommended to regulators, in particular for the current financial reform of corporate boards.
\end{abstract}

Keywords: Bank performance, corporate governance, Panel data, Agency theory

\section{INTRODUCTION}

In the current era, corporate governance took more attention and interest in every organization. Corporate governance is more grown in the banking industry, especially the failure banks including Lehman Brothers bank, Merrill Lynch Bank, Northern Rock Bank, Freddie Mac Bank, Fannie Mae Bank, HPOS bank, Washington Mutual Bank and UBS bank in the US and Europe. There was a need to introduce strong corporate governance which verified country level and international level by different developments and standards such as US Sarbanes- Oxley Act 2000, UK Combined Code, Australia CLERP 9, and the Organization for Economic Development [OECD] Code.

The main purpose of corporate governance is to establish ownership structure and management structure for the confirmation of managers, whether managers are working for the benefits of shareholders or not. According to agency theory by Jensen and Meckling (1976), there is a conflict between the owner (principal) and management (agent) which create agency problem, this conflict can be related to extra consumption or make an investment in low-risk assets rather than focus on shareholder wealth maximization. Similarly, Fama and Jensen (1983) proposed that boards of director can reduce agency conflict by looking some decision and separate the management from that decisions. For example, US Sarbanes-Oxley Act presented to increase the transparency and reduce the agency cost by legislative listed firms' governance requirements.

There is the significant role of the board of directors by managers monitoring or controlling strategies decisions in the governance of banking industry (De Andres \& Vallelado, 2008). Abdullah (2004) stated that the main function of the board is to take care of the shareholders' wealth. The responsibilities of the board of directors are developing business strategies, opined that the principal objective of a board is to keep the interests of stakeholders. They

\footnotetext{
${ }^{1}$ Department of Finance \& Banking, Faculty of Administration and Economics, Kerbala University, Iraq.

${ }_{3}^{2}$ Department of Banking and Risk Management, School of Economics, Finance and Banking, University Utara Malaysia

Department of Banking and Risk Management, School of Economics, Finance and Banking, University Utara Malaysia.

\begin{tabular}{llll|l}
\hline JISR-MSSE & Volume 14 & Number 1 & Jan-June 2016 & 29
\end{tabular}
}


are responsible for organizing corporate objectives, developing strategic business plans, evaluating and monitoring the efficient implementation of business approaches and management activities (Nekhili \& Gatfaoui, 2013; Wang \& Hsu, 2013 and Abdullah, 2004).

The board operates under the mechanism of corporate governance to appoint, supervise, and remunerate the senior managers while monitoring the influence on firm's overall strategy (Campbell \& Mínguez-Vera, 2008). In banks, the board has a more significant role as compared to non-financial institutions due to extended responsibilities of regulators and depositors along with stakeholders (Macey \& O'Hara, 2003). Thus, the board of a bank plays a significant role in the execution of governance mechanism effectively (Kilic, 2015; Pathan et al., 2013). This paper is likely to expand research by its contribution towards a better understanding of the board characteristics and performance of banks in Iraq. The key focus of the study is in the composition of the board of directors, the size of the board and board gender. In banks, these measures of corporate governance and ownership play a major role. Furthermore, this study uses Return on Equity (ROE) to measure bank performance. Moreover, it also identifies that corporate governance factors which influence the performance of banks in Iraq are similar to those in western businesses. Since corporate governance was unable to attract the attention of researchers in Iraq, this study provides a better understanding of corporate governance with the performance of banks, similar to that of global markets.

\section{LITERATURE REVIEW AND HYPOTHESES DEVELOPMENT}

This segment includes the understanding of board characteristics, ownership structure, bank performance and hypothesis development. Board characteristics are explained along three dimensions of composition, size, and gender of the board. Likewise, ownership structure has three dimensions: family ownership, institution ownership, and insider ownership. Firstly, the association between the composition of board and performance of the bank is discussed. Next, the discussion includes the relationship of board size and gender, family ownership, institution ownership, and inside ownership with the performance of the bank.

\section{Board Composition and Performance of Bank}

Currently, the key issue faced by the management of the firms is the board of director's composition (Carter et al., 2003). Therefore, it is of significance importance for researchers to examine the influence of the composition of the board on the performance of banks. Several studies have agreed that high ratio of outside directors establishes the effective board (Lorsch and MacIver (1989); Mizruchi (1983); Zahra and Pearce (1989)). Furthermore, Shungu et al. (2014), Bektas and Kaymak (2009) and Pathan et al. (2007) identifies a positive correlation between independence of board and performance of Thai and Turkish banks. However, Adams and Mehran (2008) and Stančić et al. (2012) does not found any evidence of a correlation between board composition and performance of the bank. Firms with non-executive directors are independent, works in stakeholder's best interest, have better control over management and have a positive influence on performance (Borokhovich et al., 1996; Hermalin \& Weisbach, 1988). Recently, the composition of the board has become a key area of interest among governments, researchers, academicians, and debates in public forums because of the benefits associated with the availability of diversified board members in the organizations Kilic (2015). Agency theory argues that outside directors in the board hold the advantage of monitoring 
the management to keep their reputation as independent and efficient decision makers (Fama \& Jensen, 1983). The statement supports that increase in non-executive directors reduces the agency problem, as non-executive directors tend to be more vigilant in overall management and enhance the performance of banks. Consequently, we empirically test the below hypothesis:

H1: There is a positive association between board composition and performance of the bank.

\section{Board Size and Performance of Bank}

Board size denotes the aggregated number of directors in a board who have the voting rights (Ongore et al., 2015; Pugliese \& Wenstop, 2007). Board of Directors represents the mechanism of internal governance which control the agency problems in any corporate system (Li et al. 2008; Cerbioni and Parbonetti 2007). Numerous scholars articulate board size and banks' performance as opposing ways. In the first place, some researchers argued that increase in the size of the board be directly related to rising in coordination and communication problems between the members of the board (Cerbioni \& Parbonetti, 2007; Bushman et al., 2004). Arguably, as the board size increases, monitoring capacity of directors also increase. This statement supported by Klein (2002), who emphasized on large board size as compared to the small size and was related to specialized advisory and monitoring management. Likewise, Lipton and Lorsch, (1992) recommend that increasing size of the board make it difficult for the organization to call upon regular meetings. Furthermore, the decision-making process of the large board is slow which affect their ability to capture the new business opportunities (Bantel \& Jackson, 1989).

On the other hand, researchers proposed that boards with small size enhance the monitoring abilities of management (Khanchel, 2007; Yermack, 1996). They found that monitoring ability is negatively related to the size of the board. Studies have found different results when examined board size. Jensen (1993) support the small size of the board and found its positive correlation with performance. He also argued that when board size increase above seven or eight the efficiency of board decreases and CEO of the company lose control on the board. Similarly, Lipton and Lorsch, (1992) found that it becomes difficult for board members to express opinions and give ideas when some board members are above ten. Furthermore, overcrowded board results in job loss for employees, money loss for stakeholders and competitive market position for the corporation. In another scenario, a study by De Andres and Vallelado (2008) found that board size has inverted U-shaped correlation with performance, challenging the belief that efficiency increases with small board size. The study was based on commercial banks from U.S, U.K, Canada, Italy, France and Spain holding 69 boards for the year 1995-2005.

According to Agency theory, firms with the large size of the board usually have more value. The theory suggests that management of companies whose size of the board is large have less CEO domination, have more efficient monitoring which increases the overall firm performance (Fitriya \& Locke, 2012; Singh \& Harianto, 1989).

Since the influence of the size of the board on the performance of the bank show inconsistent results. This study assumed that firms with the large board have a broad range of access to the resources and have effective management monitoring and expertise. Consequently, the study will empirically test the hypothesis below:

\begin{tabular}{llll|l}
\hline JISR-MSSE & Volume 14 & Number 1 & Jan-June 2016 & 31
\end{tabular}


H2: There is a positive association between board size and bank performance.

\section{Board gender and bank performance}

Board diversity contributes better problem-solving capacity, creativity, and knowledge to manage banks. Carter et al. (2003) support the significance of diversity in a board because diversity provides new and multiple outlooks for solving any problem. Erhardt et al. (2003) and Ramly et al. (2015) also states that board diversity has a positive correlation with firm value and performance due to unique and diversified attributes associated with board members which are helpful for high-quality decisions.

Several benefits related to female board member includes educational background, communication style, personality, career expertise, and experiences. According to Liao et al., (2015), female directors make a major and broader contribution in any decision-making. However, female members are usually less oriented towards power but are more concerned and compassionate than male board directors (Ramly et al., 2015). Additionally, commitment and involvement level of women are high which enhance the process of decision making. Furthermore, they have less self-interest concern and are more hard working which increases effectiveness and performance of the corporates (Liao et al., 2015; Lucas- Pérez et al., 2015). Additionally, the attendance for female board members is high as compared to male board members and diversity also increase the monitoring ability of the board (Adams \& Ferreira 2009).

Concerning the association amongst gender variety and banks' performance, the scarce prevailing experiential finding indicates conflicting results. Ongore et al. (2015), Shungu et al. (2014), and Pathan et al. (2013) found a positive correlation amongst the proportion of women directors and banks' performance. Conversely, Kilic (2015) found an adverse correlation between gender diversity and bank performance. Meanwhile, Liang, Xu, \& Jiraporn (2013) show no significant association amongst the proportion of women on the board of directors and banks' performance.

Agency theory opines that better monitoring of managers is linked with the diverse board because diversity enhances the independence of board (Carter et al., 2007). Board independence provides enhanced monitoring which has a positive correlation with the performance of the firm. Therefore, board diversity represented by gender diversity may improve the board mechanism of management monitoring and control and may also enhance board independence (Campbell \& Minguez-Vera, 2008). Consequently, the hypothesis concerning board gender which is to be tested empirically is stated as:

H3: There is a positive association between board gender and bank performance.

\section{Other Variables}

\section{Bank Size}

The firm size is linked with economies of scale and has a probability of improving the financial performance of the organizations. Similar to previous researchers, this study has employed bank size as a control variable (Al-Saidi \& Al-Shammari, 2013).

\begin{tabular}{l|llll}
\hline 32 & Jan-June 2016 & Volume 14 & Number 1
\end{tabular}




\section{Non-Performing Loans (NPL)}

According to Hu et al. (2004) controlling NPL is essential for the bank performance. Also, El-Chaarani (2014) and Zhang \& Yang (2011) assert that NPL has been widely used to control the effects of corporate governance to bank performance, and have been found to be significant.

\section{RESEARCH METHOD}

This segment includes the employment of sample and sources of data and econometric model.

\section{Data and Model Specification}

To measure bank performance, this study use ROE, which defined as net income of the bank after deduction of tax by employing its total equity (Liang et al., 2013). Board characteristics is in three dimensions: Board composition (BODC), board size (BODS) and board gender (BODG). In line with the studies of Lefort and Urzúa (2008) board composition (BODC) is calculated by the number of non-executive directors in bank's board. The size of the board is the representation of a total number of board directors (Fanta, Kemal, Waka, 2013). Board gender is the proportion of directors on board which is female (Liang et al., 2013). The bank size (BANKZ) is measured by taking the natural log of banks assets. (Al-Saidi \& Al-Shammari, 2013). Non-performing loans represent the ratio of loans which are not performing to total loans in each bank at year end (Zhang \& Yang, 2011). As far as this work is concerned, a total sample of 24 commercial banks in Iraq was used. Data is obtained from annual financial reports of the 24 commercial banks in Iraq for the year 2005-2014. Total observations in the sample are 240 .

The study used panel data tests to investigate the effect of characteristics of the board on the performance of banks. By using Panel data analysis, estimation biases can be reduced to the maximum extent, overcoming the issues of multicollinearity. This provides time-variant relationship while analyzing the correlation among independent and dependent (Baltagi, 2001). The proposed model for this study is:

$\mathrm{ROE}_{i t}=\beta_{0}+\beta_{1} \mathrm{BODC}_{\mathrm{it}}+\beta_{2} \mathrm{BODS}_{\mathrm{it}}+\beta_{3} \mathrm{BODG}_{\mathrm{it}}+\beta_{4} \mathrm{BANKZ}_{\mathrm{it}}+\beta_{5} \mathrm{NPL}_{\mathrm{it}}+\mathrm{e}_{\mathrm{it}}$

Where; ROE $=$ Return on Equity, BODC $=$ Board Composition, BODS $=$ Board Size, BODG $=$ Board Gender, $\mathrm{BANKZ}=$ Bank Size, NPL $=$ Non-Performing Loan, $\mathrm{e}_{\mathrm{it}}=$ Error term.

\section{RESULTS AND DISCUSSIONS}

This section makes an assessment of the results and findings. This research paper's hypotheses were in order to determine whether or not they held up to their theoretical assumptions. This section consists of the descriptive data which was analyzed first, followed by correlation analysis, followed by panel data regressions and, finally, a discussion of the results 


\section{Descriptive Statistics}

Table 1

Descriptive Statistics for all ten years from 2005 to 2014

\begin{tabular}{lrrrrr}
\hline Variables & Unit. & Mean & St. Dev. & Min & Max \\
\hline ROE & Ratio & 0.1397 & 0.1215 & -0.1287 & 0.280 \\
BORDC & Ratio & 0.3133 & 0.1960 & 0.1111 & 0.688 \\
BORDS & Number & 6.0600 & 1.2756 & 5 & 9 \\
BORDG & Ratio & 0.4344 & 0.1840 & 0.0123 & 0.8 \\
Total Assets & USD & 236537538 & $2.71 \mathrm{E}+08$ & 2439427 & $1.64 \mathrm{E}+09$ \\
NPL & Ratio & 0.2100 & 0.0958 & 0.0235 & 0.4397 \\
\hline
\end{tabular}

Table 1 consists of the descriptive statistics which gives a snap shot of the data and the relationships which exist within the presented data's variables. Board composition stood at close to $31 \%$ with a minimum of $11 \%$ and maximum of $68 \%$. The board size was approximately 6.06 with a minimum of 5 and a maximum of 9 . The board gender ranged from a minimum of 0.01 to a maximum of 0.8 with an approximation of 0.43 . The total assets of the Iraqi banks were approximately million \$236.537538 with a minimum of million \$2.439427 and maximum of billion $\$ 1.64$. The non-performing loan ranged from a minimum of $2.35 \%$ to a maximum of $43.79 \%$ years with an approximation of $21 \%$.

\section{Correlation Analysis}

In this section, the correlation analysis is carried out. Correlation analysis is useful in describing the strength and sign of the linear relationship between two variables. More specifically, the Pearson correlation analysis was employed to assess and clarify the strengths of the linear relationship among the study variables as provided in table 2 . The correlation coefficient $(r)$ values given in table 2 shows the strength of the relationship among variables. Correlation coefficient value of 0 shows no linear relationship, while the correlation coefficient value of \pm 1.0 shows perfect linear relationship. On the other hand, interpreted the correlation coefficient value between 0 and 1.0 as follows; the correlation (r) between \pm 0.1 and \pm 0.29 shows weak relationship, between \pm 0.30 and \pm 0.49 shows medium correlation and above \pm 0.50 shows strong relationship (Hair et al., 2010).

Overall, the results shows that all correlations between independent variables are less than 0.80 . This indicates that there is no multicollinearity problem. Gujarati (2004) says that the correlation between independent variables should not exceed 0.80 to ensure that there is no multicolinearity. 
Table 2.

Pearson Correlation Analysis

\begin{tabular}{lcccccc}
\hline Probability & ROE & BORDC & BORDS & BORDG & BANKSZ & NPL \\
\hline ROE & 1 & & & & & \\
BORDC & $0.330^{* * *}$ & 1 & & & & \\
BORDS & $0.259^{* * *}$ & -0.039 & 1 & & & \\
BORDG & $0.152^{* * *}$ & $0.152^{* * *}$ & $0.444 * * *$ & 1 & & \\
BANKSZ & $0.101^{*}$ & $0.180^{* *}$ & -0.065 & $-0.096^{*}$ & 1 \\
NPL & $-0.393^{* * *}$ & $-0.252^{* * *}$ & -0.086 & $-0.280^{* * *}$ & 0.074 & 1 \\
\hline
\end{tabular}

$*, * *$ and $* * *$. Correlation is significant at the 0.10 level, 0.05 level, .01 respectively.

\section{Regression analysis}

In this section, the empirical examination of the influence of board characteristics on the performance of the bank is presented and discussed. Table 3 illustrates the panel tests to select the appropriate model, fixed effects, random effects or pooled OLS. The first test is Haussmann test to compare between random and fixed effects. For Haussmann test, when the p-value is lower than 0.05 that mean fixed effect is the more appropriate for the model. The second criterion is FE test to compare between fixed effects and pooled OLS. The pvalue for FE test is higher than 0.05 that mean pooled OLS is the more appropriate model.

Table 3

Board characteristics and bank performance (ROE)

\begin{tabular}{lclc}
\hline Variable & Coefficient & t-Statistic & Prob. \\
\hline Constant & 0.2013 & 1.3364 & 0.1824 \\
BODC & $0.1596^{* *}$ & 5.0065 & 0.0000 \\
BODS & $0.0241^{* *}$ & 5.4405 & 0.0000 \\
BODG & $-0.1046^{*}$ & -1.8449 & 0.0660 \\
BANKZ & $0.0333^{*}$ & 1.8254 & 0.0689 \\
NPL & $-0.6558^{* *}$ & -6.6149 & 0.0000 \\
R-squared & 0.2880 & & \\
Adjusted R-squared & 0.2765 & & \\
F-statistic & 25.164 & & \\
Prob(F-statistic) & 0.0000 & & \\
\hline Diagnostic Tests & P-value & Results & \\
\hline Hausman Test & 0.0023 & Fixed Effects & \\
FE Test & 0.2954 & Pooled OLS & \\
\hline Normality & 0.4395 & The residual normally distributed & \\
Serial Correlation & 0.2395 & There is no serial correlation problem & \\
Heteroscedasticity & 0.0845 & The residuals are homosceasticity & \\
\hline Note * & &
\end{tabular}

Note: *and $* *$ indicates significance at the $10 \%$ and $1 \%$ level respectively. 
The regression result is shown in table 3, the regression equation employed ROE as its dependent variable and board composition, board size, and board gender as independent variables. Bank size and non-performing loan are control variables. Diagnostic tests: normality teat, serial correlation test, and heteroscedasticity test were used in analyzing the estimated model. It is also found from Table 1 that BODC, BODS, BODG, BANKZ and NPL are significant in explaining variations in ROE. Nevertheless, not all the significant variables are found to meet the expected sign or support the hypotheses. The positive sign of the coefficient of BODC, BODS, and BANKZ indicate that an increase in BODC, BODS and BANKZ by one unit will increase ROE by 0.1596 units 0.0241 units, and 0.0333 units respectively. While, the negative sign of the coefficient of BODG and NPL indicates that, an increase in BODG and NPL by one unit will decrease ROE by 0.1046 units and 0.6558 units respectively. Table 1.3 illustrates also, normality teat, serial correlation test, and heteroscedasticity test. The p-value in all tests are insignificant $(\mathrm{P}>0.05)$, that mean the residual normally distributed and there is no autocorrelation and hetroskedasticity issues in the model.

Table 3 demonstrates that Board composition (ratio of non-executive directors) has a positive correlation with the performance of banks, implying that an increased in the non-executive directors of a bank increase its performance. These results support agency theory, which claims that the board with a high percentage of outside director results in better firm performance. Additionally, this finding is consistent with El-Chaarani (2014); Shungu et al. (2014); Zhang \& Yang (2011); Bektas \& Kaymak (2009) and Pathan et al. (2007) findings. Based on the results, the hypotheses of a significant positive relationship between board gender and performance of the bank is supported.

Table 1.3 illustrates that performance of bank and size of the board has a positive correlation. Furthermore, it improves the performance of the bank. These results support agency theory, which claims that the board with large size results in better firm performance. Additionally, this finding is consistent with Nodeh (2016); Stepanova and Ivantsova (2012); Adams and Mehran (2012); Belkhir (2009). Based on the results, the hypotheses of a significant positive relationship between board size and performance of the bank is supported. Furthermore, De Andres and Vallelado (2008) and Klein (2002) emphasized that large board size improve the advisory and have effective monitoring of the management as compared to the small size. Thus, banks in Iraq with a large number of board directors have the advantage of more efficiency and accountability of their operations.

In general, firms having a large number of female board members have the benefit of pooling a better human capital which provides better directors with different perspectives having additional skills as compared with firms having all male directors. Nonetheless, agency theory and relationship of female directors with the performance of bank are inverse to each other. Since agency theory supports the diversity which is helpful in reducing decision dominations and providing diversified viewpoints. Findings of the current study are similar to Kilic, 2015 for banks in Turkey but the opposite of Pathan et al. (2013) for banks in the USA. As far as this study is a concern, the result rejects the testable hypothesis (H3). This implies that banks in Iraq do not found a significant correlation of female member of the board with the performance of banks.

\begin{tabular}{l|lll}
\hline 36 & Jan-June 2016 & Volume 14 & Number 1
\end{tabular}


Moreover, findings show that size of the bank has a positive influence on bank performance, which is according to the notion that large bank tends to have the ability for efficiency improvement through resource consolidation and alliance with other banks (Arouri, 2011). Nonetheless, the percentage of non-performing loan has a significant negative influence on performance as measured by ROE, which is according to the notion that non-performing loan in the financial sector increases the possibility to lead establishment to difficulty and worse bank performance (Messai \& Jouini, 2013).

The overall findings depict that practices of governance in Iraq banks are good, including board characteristics (the number of directors, composition, and gender of the board). These variables are significantly linked with bank' performance across financial measure ROE.

\section{CONCLUSION AND RECOMMENDATION}

The study empirically examined the influence of board characteristics on bank financial performance. In previous research, researchers have emphasized on the relationship of board characteristics and bank performance in developed and developing countries. This study is among few other studies which empirically examined the correlation between board characteristics and the bank financial performance in Iraq.

The analysis carried out in the scope of this paper allowed us to advance in the understanding of the impacts of board characteristics on financial performance, by empirically examining commercial banks in Iraq. In general, the findings provide evidence that board composition has a positive correlation with the performance of commercial banks in Iraq. While examining the board size, this study found that large board size has effective monitoring of the management as compared to the small size. Thus, banks in Iraq with a large number of board directors have the advantage of more efficiency and accountability of their operations and positively improve the performance of banks. As for board gender, the findings suggest that the gender diversity of the board members worsen the performance of banks in Iraq. The paper, therefore, recommends that banks committed toward the enhancement of performance should establish more non-executive directors, big-sized boards of directors, composed of few female directors in the board.

Moreover, the results of this paper provide a bridge for future research. For any potential researchers need to replicate and reinvestigate the argument introduced here in other contexts. Second, examining how the board characteristics and financial performance varies with a bank's life cycle is likely to be considered for future research. It is important as corporate governance parameters may be related to strategic thresholds in the life cycle of banks. Third, future research is encouraged to empirically examine the moderating or mediating impact among the board characteristics, and financial performance. Lastly, to keep the balanced skills in the boardroom, Iraqi banks may require larger boards with a high percentage of nonexecutive directors by incorporating more male directors in their operations. 


\section{REFERENCES}

Abdullah, S. N. (2004). Board composition, CEO duality and performance among Malaysian listed companies. Corporate Governance: The international journal of business in society, 4(4), 47-61.

Adams, R. B., \& Ferreira, D. (2009). Women in the boardroom and their impact on governance and performance. Journal of financial economics, Elsevier, 94(2), 291-309.

Adams, R. B., \& Mehran, H. (2008). Corporate Perfomance, Board Structure and Their Determinants in the Banking Industry. Staff Report, Federal Reserve Bank of New York, No. 330.

Adams, R. B., \& Mehran, H. (2012). Bank Board Structure and Performance: Evidence for Large Bank Holding Companies. Journal of Financial Intermediation, Elsevier, 21(2), 243-267.

Al-Saidi, M., \& Al-Shammari, B. (2013). Board Composition and Bank Performance in Kuwait: An Empirical Study. Managerial Auditing Journal, Emerald, 28(6), 472-494.

Arouri, H., Hossain, M., \& Muttakin, M. B. (2011). Ownership Structure, Corporate Governance and Bank Performancew: Evidence from GCC Countries. Corporate Ownership \& Control, 8(4), 365-372.

Baltagi, B. (2001), Econometric Analysis of Panel Data, John Wiley \& Sons, Chichester.

Bantel, K. A., \& Jackson, S. E. (1989). Top management and innovations in banking: Does the composition of the top team make a difference?. Strategic Management Journal, 10, 107-124.

Bektas, E., \& Kaymak, T. (2009). Governance Mechanisms and Ownership in an Emerging Market: The Case of Turkish Banks. Emerging Markets Finance and Trade, 45(6), 20-32.

Belkhir, M. (2009). Board of Directors' Size and Performance in the Banking Industry. International Journal of Managerial Finance, Emerald, 5(2), 201-221.

Borokhovich, K. A., Parrino, R., \& Trapani, T. (1996). Outside directors and CEO selection. Journal of Financial and Quantitative Analysis, 31(03), 337-355.

Bushman, R. M., Piotroski, J. D., \& Smith, A. J. (2004). What determines corporate transparency?. Journal of accounting research, 42(2), 207-252.

Campbell, K., \& Minguez-Vera, A. (2008). Gender Diversity in the Boardroom and Firm Financial Performance. Journal of Business Ethics, Springer, 83(3), 435-451.

Carter, D. A., Simkins, B. J., \& Simpson, W. G. (2003). Corporate governance, board diversity, and firm value. Financial review, 38(1), 33-53.

\begin{tabular}{l|lll}
\hline 38 & Jan-June 2016 & Volume 14 & Number 1
\end{tabular} 
Carter, D. A., Souza, F. D., Simkins, B. J., \& Simpson, W. G. (2007). The Diversity of Corporate Board Committees and Firm Financial Performance. SSRN Electronic Journal, 1-40.

Cerbioni, F., \& Parbonetti, A. (2007). Exploring the effects of corporate governance on intellectual capital disclosure: an analysis of European biotechnology companies. European Accounting Review, Taylor \& Francis, 16(4), 791-826.

De Andres, P., \& Vallelado, E. (2008). Corporate Governance in Banking: The Role of the Board of Directors. Journal of Banking \& Finance, Elsevier, 32(12), 2570-2580.

El-Chaarani, H. (2014). The Impact of Corporate Governance on the Performance of Lebanese Banks. The International Journal of Business and Finance Research, 8(5), 35-64.

Erhardt, N. L., Werbel, J. D., \& Shrader, C. B. (2003). Board of Director Diversity and Firm Financial Performance. Corporate Governance: An International Review, 11, $102-$ 111.

Fama, E. F., \& Jensen, M. C. (1983). Separation of ownership and control. The Journal of Law \& Economics, 26(2), 301-325.

Fanta, A., Kemal, K., \& Waka, Y. (2013). Corporate governance and impact on bank performance. Journal of Finance and Accounting, 1(1), 19-2.

Fitriya, F., \& Locke, S. (2012). Board Structure, Ownership Structure and Firm Performance: A Study of New Zealand Listed-Firms. Asian Academy of Management Journal of Accounting and Finance, 8(2), 43-67.

Gujarati, D. (2004). Basic Econometrics (4th ed.). New York: McGraw-Hill.

Hair, J. F., Anderson, R. E., Tatham, R. L., \& Black, W. C. (1998). Multivariate Data Analysis. (N. Upper Saddle River, Ed.) (2nd Edition). New York: Prentice-Hall.

Hermalin, B., Weisbach, M., 1988. The determinants of board composition. Rand Journal of Economics 19, 589-606.

Hu, J. L., Li, Y., \& Chiu, Y. H. (2004). Ownership and Nonperforming Loans: Evidence from Taiwan's Banks. The Developing Economies, 42(3), 405-420.

Jensen, M. C. (1993). The modern industrial revolution, exit, and the failure of internal control systems. The Journal of Finance, 48(3), 831-880.

Jensen, M. C., \& Meckling, W. H. (1976). Theory of the Firm: Managerial Behavior, Agency Costs and Ownership Structure. Journal of Financial Economics, Elsevier, 3(4), 305360 .

Khanchel, I. (2007). Corporate governance: measurement and determinant analysis. Managerial Auditing Journal, 22(8), 740-760.

\begin{tabular}{llll|l}
\hline JISR-MSSE & Volume 14 & Number 1 & Jan-June 2016 & 39
\end{tabular}


Kilic, M. (2015). The Effect of Board Diversity on the Performance of Banks: Evidence from Turkey. International Journal of Business and Management, 10(9), 53-88.

Klein, A. (2002). Audit Committee, Board of Director Characteristics, and Earnings Management. Journal of Accounting and Economics 33(3), 375-400.

Lefort, F., \& Urzúa, F. (2008). Board independence, firm performance and ownership concentration: Evidence from Chile. Journal of Business Research, Elsevier, 61(6), $615-622$.

Li, J., Pike, R., \& Haniffa, R. (2008). Intellectual capital disclosure and corporate governance structure in UK firms. Accounting and Business Research, Taylor \& Francis, 38(2), 137-159.

Liang, Q., Xu, P., \& Jiraporn, P. (2013). Board Characteristics and Chinese Bank Performance. Journal of Banking \& Finance, Elsevier, 37(8), 2953-2968.

Liao, L., Luo, L., \& Tang, Q. (2015). Gender diversity, board independence, environmental committee and greenhouse gas disclosure. The British Accounting Review, Elsevier, 47(4), 409-424.

Lipton, M. and Lorsch, J., W. (1992). A modest proposal for improved corporate governance. Business Lawyer, 48(1), 59-77.

Lorsch, J. W., \& MacIver, E. (1989). Pawns or Potentates: The Reality of America's Corporate Boards. Boston: Harvard University Press.

Lucas-Pérez, M. E., Mínguez-Vera, A., Baixauli-Soler, J. S., Martín-Ugedo, J. F., \& SánchezMarín, G. (2015). Women on the board and managers' pay: Evidence from Spain. Journal of Business Ethics, Springer, 129(2), 265-280.?

Macey, J. R., \& O'Hara, M. (2003). Solving the corporate governance problems of banks: A proposal. Banking LJ, 120, 326.

Messai, A. S., \& Jouini, F. (2013). Micro and Macro Determinants of Non-performing Loans. International Journal of Economics and Financial Issues, 3(4), 852-860.

Mizruchi, MS. (1983). Who controls whom? An examination of the relation between management and boards of directors in large American corporations. Acudemy of Munugement Review, 8, 426-435.

Nekhili, M., \& Gatfaoui, H. (2013). Are demographic attributes and firm characteristics drivers of gender diversity? Investigating women's positions on French boards of directors. Journal of business ethics, Springer, 118(2), 227-249

Nodeh, F. M., Anuar, M. A., Ramakrishnan, S., \& Raftnia, A. A. (2016). The Effect of Board Structure on Banks Financial Performance by Moderating Firm Size. Mediterranean Journal of Social Sciences, 7(1), 258-263.

\begin{tabular}{l|lll}
\hline 40 & Jan-June 2016 & Volume 14 & Number 1
\end{tabular} 
Ongore, V. O., Peter, O. K., Ogutu, M., \& Bosire, E. M. (2015). Board Composition and Financial Performance: Empirical Analysis of Companies Listed at the Nairobi Securities Exchange. International Journal of Economics and Financial Issues, 5(1), 23-39.

Pathan, S., Faff, R., \& Gray, P. (2013). Does Board Structure in Banks Really Affect Their Performance? Journal of Banking and Finance, Elsevier, 37(5), 1573-1589.

Pathan, S., Skully, M., \& Wickramanayake, J. (2007). Board size, Independence and Performance: An Analysis of Thai Banks. Asia-Pacific Financial Markets, 14(3), 211227.

Pugliese, A., Wenstop, P.Z. (2007), Board member contribution to strategic decision making in small firms, Journal of Management and Governance, 11(4), 383-404.

Ramly, Z., Sok-Gee, C., Mustapha, M. Z., \& Sapiei, N. S. (2015). Gender Diversity, Board Monitoring and Bank Efficiency in Asean-5. South East Asia Journal of Contemporary Business, Economics and Law, 7(1), 9-21.

Shungu, P., Ngirande, H., \& Ndlovu, G. (2014). Impact of Corporate Governance on the Performance of Commercial Banks in Zimbabwe. Mediterranean Journal of Social Sciences , MCSER Puplishing, Roma, Italy, 5(15), 93-105.

Singh, H., \& Harianto, F. (1989). Management-Board Relations, Takeover Risk, and the Adoption of Golden Parachutes. Academy of Management Journal, 32(1), 7-24.

Stančić, P., Čupić, M., \& Barjaktarović Rakočević, S. (2012). Influence of Board Size and Composition on Bank Performance - Case of Serbia. Actual Problems of Economics, $134,466-475$.

Stepanova, A., \& Ivantsova, O. (2012). Role of Corporate Governance in Banking Sector?: Evidence from All Over the World. Electronic Journal of Corporate Finance, 4(24), 80-86.

Wang, T., \& Hsu, C. (2013). Board composition and operational risk events of financial institutions. Journal of Banking \& Finance, Elsevier, 37(6), 2042-2051.?

Yermack, D. (1996). Higher Market Valuation of Companies with a Small Board of Directors. Journal of financial economics, Elsevier, 40(2), 185-211.?

Zahra, S. A., \& Pearce, J. A. (1989). Boards of Directors and Corporate Financial Performance: A review and integrative model. Journal of management, 15(2), 291-334.?

Zhang, J., \& Yang, J. (2011). Corporate Governance and Performance of Listed Commercial Banks during Financial Crisis: Evidence from China's Banking Industry. Journal of the Washington Institute of China Studies, 5(4), 1-21. 